\title{
REVIEW: DIAPAUSE IN CRUSTACEANS AND ITS ECOLOGICAL AND BIOGEOGRAPHICAL IMPLICATIONS: AN EXAMPLE FROM PATAGONIAN EPHEMERAL POOLS
}

\author{
REVISIÓN: DIAPAUSA EN CRUSTÁCEOS Y SUS IMPLICANCIAS ECOLÓGICAS \\ Y BIOGEOGRÁFICAS: UN EJEMPLO EN LAS POZAS PATAGÓNICAS
}

Patricio De los Ríos-Escalante ${ }^{1,2} \&$ Cinthia Robles ${ }^{3}$

\begin{abstract}
The production of diapause eggs is a strategy for survival adopted by microcrustaceans living under adverse environments. This strategy also, aids dispersion and colonization in new environments. In the long term, this colonization process can enhanced genetic isolation as the first step in the process of species evolution. The present study is: (a) wider review of the diapause process in inland water crustaceans and its ecological, evolutionary and biogeographical implications, and (b) it's application to microcrustacean assemblages in inland waters in southern Patagonia. In the literature the diapause strategy was described from anostracans, cladocerans and copepods as microcrustaceans, and amphipoda in malacostracan crustaceans. High crustacean species richness was recorded from Southern Patagonia, this region having species of southern South American and Sub-Antarctic islands origin. Their spatial distribution is probably explained by the presence of migratory birds. Also, many habitats of the microcrustaceans are ephemerals, that would be studied under metapopulation and metacommunities view point.
\end{abstract}

Key words: diapause, colonization, metapopulations, metacommunities, anostracans, cladocerans, copepods.

\section{RESUMEN}

Los microcrustáceos tienen como estrategias del ciclo de vida la generación de huevos en estado de diapausa bajo condiciones ambientales adversas, esta estrategia provee facilidades para la dispersión que generan procesos de colonización los que estimulan procesos de aislamiento genético como primer

\footnotetext{
1 Escuela de Ciencias Ambientales, Facultad de Recursos Naturales, Universidad Católica de Temuco, Casilla 15-D, Temuco, Chile.prios@uct.cl

2 Núcleo de Estudios Ambientales, UC Temuco.

${ }^{3}$ Escuela de Pedagogía Media, Facultad de Educación, Universidad Católica de Temuco, Casilla 15-D, Temuco, Chile.
} 
paso de procesos de especiación. El presente estudio es una revisión sobre los procesos de diapausa en crustáceos de aguas continentales y sus implicancias ecológicas, evolutivas y biogeográficas y se aplicará esto a la realidad de aguas continentales de la Patagonia.

La literatura describe la presencia de anostracos, cladóceros y copépodos como microcrustáceos y anfípodos como malacostracos y todos estos grupos tienen diapausa como estrategia. La literatura describe alta riqueza de crustáceos en el sur de la Patagonia, y esta región tiene especies del sur de Sudamérica y de islas sub-Antárticas y es probable que la presencia de aves migratorias que explicarían la distribución espacial de estas especies. De igual modo, muchos habitats de microscrustáceos son lagunas temporales que podrían ser explicadas bajo el punto de vista de metapoblaciones y metacomunidades.

Palabras clave: diapausa, colonización, metapoblaciones, metacomunidades, anostracos, cladóceros, copépodos.

\section{INTRODUCCIÓN}

Microcrustaceans such as Branchiopoda, Copepoda and Ostracoda have diapause egg production- the generation of restings eggs - as a life strategy for species perpetuation under adverse environments, specifically drying of their habitats (Alekseev, 2007a;b;2010;Alekseev et al. 2007; Muñoz, 2009). This life strategy has many ecological, systematic and evolutionary implications. Resting eggs, can be spread by agents such as wind and other fauna and initiate the colonization process in new habitats or habitats where microcrstaceans have been been reduced or disappeared from. This could have impacts on metapopulations and metacommunities (Altermatt, 2008). This spreading and colonization dynamics would have evolutionary and systematic implicantions as, if the resting eggs colonize new habitats with environmental heterogeneity, selection pressure would eliminate all individuals other than those with optimal genes for survival and reproduction, and as a consequence would create genetic isolation as the first step in the speciation process (De los Ríos \& Zúñiga, 2000; Gajardo et al. 1995; 2004; Ebert et al. 2002). This scenario, over a wide spatial and temporal scale could create zones where certain taxa could originate, spread and colonize new, more distal habitats as the first step in a potential speciation process, that could be described using biogeographical techniques, such as track analysis or endemicity parsimony analysis (Morrone, 2004; 2006).

In Patagonia $\left(38-54^{\circ} \mathrm{S}\right)$ there are many ephemeral pools (formed in spring, and disappearing over the other seasons), that would contain crustaceans that generate resting eggs. These subsequently hatch when the environmental conditions are optimal (De los Ríos-Escalante, 2010). From a biogeographical view point, Patagonia has species from Southern South America and Sub-Antarctic islands (MenuMarque et al. 2000; Pugh et al. 2002; Dos Santos et al. 2008). Within this scenario, the aim of the present study is to review diapause strategies of microcrustaceans in general with emphasis on biogeographical and ecological implications and apply this to a study of microcrustacean (Branchiopoda, Copepoda, and Amphipoda) species distribution in Patagonian inland waters.

\section{BRANCHIOPODA}

The branchiopods described for Patagonia include Anostracans (families Artemiidae and Branchinectidae), and Cladocerans (families Daphnidae, Bosminidae, Chydoridae), with both endemic and cosmopolitan species (De los Ríos-Escalante, 2010). Both Anostracan families Artemiidae and Branchinectidae are present in saline and freshwater lakes and pools respectively (De los Ríos-Escalante, 2010). The Artemiidae is represented by the species Artemia persimilis (Piccinelli \& Prosdocimi, 1968) , found in two saline lakes in the Magallanes region, Laguna Amarga (51 $01^{\circ} \mathrm{S}$ : $72^{\circ} 48^{\prime} \mathrm{W}$ ) in Torres del Paine National Park and Laguna de los Cisnes (53 ${ }^{\circ} 14^{\prime}$ S: $70^{\circ} 23^{\prime} \mathrm{W}$ ) close to Porvenir on Tierra del Fuego (De los Ríos-Escalante \& Gajardo, 2010). The population in Laguna Amarga is permanent and practically exclusive to the zooplankton of this habitat (Campos et al., 1996), whereas the popula- 
tion in Laguna de los Cisnes depends on variations in salinity- it can be present at high salinity levels, but if the salinity decreases, the population disappears (De los Ríos-Escalante \& Gajardo, 2010). For Branchinectidae, the species Branchinecta gaini and $B$. granulosa are reported from the Magallanes region at 53 and $51^{\circ} \mathrm{S}$ respectively, B. vuriloche from the Aysen region at $45^{\circ} \mathrm{S}$ (Rogers et al. 2008) and juvenile specimens in coastal ponds in the Araucania region at $38^{\circ} \mathrm{S}$ (De los Ríos-Escalante et al. 2010). Branchinecta are found in ephemeral pools present only in spring, and this genus is probably confined to oligotrophic and low conductivity inland waters (De los Ríos et al. 2008). The cladocerans have species with cosmopolitan distibutions and endemic species (De los Ríos-Escalante, 2010) such as Ceriodaphnia dubia Richard, 1894, Daphnia ambigua Scourfield, 1947, D. dadayana, Paggi, 1999, D. pulex Leydig, 1860; Scapholeberis exsipinifera (Nicolet, 1849); Simosa exspinosa (De Geer, 1778), Neobosmina chilensis (Daday, 1902), Ilyocryptus spinifer Herrick, 1884; Alona poppei Richard, 1897, A. pulchella King, 1853, A. quadrangularis (O.F. Müller, 1776), A. clathratula (G.O. Sars, 1896), Alonella excise (Fisher, 1854), Camptocercus rectirrostris (Schoedler, 1862), Pleuroxus aduncus (Jurine, 1820), Chydorus sphaericus (O.F. Müller, 1785), Leydigia leydigi (Schoedler, 1863) and Paralona nigra (G.O. Sars, 1862). The cladocerans from the northern hemisphere that produce diapause resting eggs have been studied (Altermatt, 2008; Muñoz, 2009) and although a life strategy of sexual and asexual generations is reported, this situation has not been reported for southern hemisphere populations (Adamowicz et al. 2002).

\section{COPEPODA}

The free living copepoda reported for $\mathrm{Pa}$ tagonian inland waters are mainly Calanoids and Cyclopoids. The Calanoid copepods include species reported exclusively from the Southern hemisphere, some species being widespread between tropical and southern South America (De los Ríos-Escalante, 2010): Boeckella gracilipes Daday, 1902, B. gracilis (Daday, 1902), B. meteoris Kiefer, 1928, whereas other species are endemic to southern south America and/or Sub-Antarctic islands such as B. brasiliensis (Lubbock, 1855), B. brevicaudata
(Brady, 1875), B. michaelseni (Mrázek, 1901), B. poppei (Mrázek, 1901) and Parabroteas sarsi (Ekman, 1905). Amongst the Cyclopoids there are mainly endemic species from Southern South America (De los Ríos-Escalante, 2010), such as Acanthocyclops michaelseni (Mrázek, 1901), A. vernalis (Fisher, 1853), Eucyclops ensifer Kiefer, 1936, Eucyclops serrulatus (Fisher, 1851), Macrocyclops albidus (Jurine, 1820), Mesocyclops araucanus (Löffler, 1962), Metacyclops mendocinus (Wierzejski, 1892), Microcyclops anceps (Richard, 1897), Paracyclops fimbriatus chiltoni (Thomson, 1882) and Tropocyclops prasinus meridionalis Kiefer, 1927. Only the species Mesocyclops logisetus (Thiébaud, 1912) is distributed among all geographical gradients in tropical and subtropical South America. There are no reported studies of diapause in South American inland water copepods, the available information is for New Zealand copepods (Cough et al., 2001; Hall \& Burns, 2001; Banks, 2007; Taylor 2010), and for Antarctic population of B. poppei (Jiang et al. 2012). Nevertheless, the presence of the abovementioned species in ephemeral pools would indicate the presence of diapause life strategies in copepods (De los Ríos-Escalante, 2010).

\section{AMPHIPODS}

The amphipods reported from Southern Patagonia included species reported for southern South America (De los Ríos-Escalante et al., 2012) such as Hyalella costera González \& Watling, 2001, H. chiloensis González \& Watling, 2001, H. curvispina Schoemaker, 1942, H. franciscae González \& Watling, 2003, H. patagonica (Cunningham, 1871), H. rionegrina (Grosso \& Peralta, 1999) and H. simplex (Schellenberg, 1943). Although there are no reported studies of diapause in southern freshwater amphipods, the presence of species in ephemeral pools and wetlands with drying and flooding periods such as Tres Puentes wetlands close to Punta Arenas, and some ephemeral pools close to Puerto Natales, would indicate the presence of diapause mechanism to explain the presence of these amphipods (De los Ríos-Escalante, personal observations, February 2012). Diapause has been observed for Hyalella azteca (Bayley et al., 2005; Doobay 2011; Alekseev, 2007a), a widespread species from the American continent (De los Ríos- 
Escalante et al., 2012), nevertheless there are no published accounts of diapause in South American amphipods.

\section{ECOLOGICAL IMPLICATIONS}

In ecology, the metapopulation and metacommunities concepts are currently widely used to explain the presence of interconnected sub-units where individuals continuously migrate with the consequent local colonization and extinction process (De los Ríos-Escalante, 2012). In this scenario, metapopulation and metacommunities can be used to explain faunal populations in plains such as coastal zones (Puaucho sand beaches), flooded after rainy season or mountain zones such as Cañi Park or zones close to Lonquimay in Araucania region, or pools close to Balmaceda airport in the Aysen region, or in the Magallanes region (De los Ríos-Escalante, 2010; 2012). The main characteristic of these habitats is the presence of many isolated pools during spring. In summer these habitats dry out, and in autumn and winter these can be snow covered (in for example the Lonquimay, Balmaceda or Magallanes pools), or filled with water from winter rains (Puaucho pools) (De los Ríos-Escalante, 2012). The exceptions are the pools in Cañi which can remain water-filled in summer (De los Ríos \& Roa, 2010). These pools are characterized by a relatively homogeneous species diversity regulated mainly by trophic status and/ or conductivity (De los Ríos \& Roa, 2010; De los Ríos-Escalante 2012). No systematic studies have been conducted on the occurrence and distribution of pools on the Patagonian plains. These are however present only one or two months after winter rains, and inhabited by characteristic crustaceans for each region, -for example Boeckella poppei, Daphnia dadayana and Parabroteas sarsi in central and southern Patagonia, or Boeckella gracilis and Daphnia pulex in northern Patagonia (De los Ríos, personal observations; De los Ríos-Escalante, 2010; 2012). In Laguna de los Cisnes lagoon, where there are marked variations in response to seasonal salinity variations, it is proposed that these might result in the presence of only Artemia persimilis at high salinity, but at intermediate salinity the Artemia can coexist with other halophilic copepods such as harpacticoids and $B$. poopoensis, and at low salinity $A$. persimilis is not found and is replaced by $B$. poopoensis and harpacticoid copepods (De los Ríos-Escalante \& Gajardo, 2010).

It was reported in the literature that diapause egg production can be induced by direct or indirect predator exposure, specifically the presence of fish kairomones (semiochemicals emitted by the fish which benefit the recipient organism) that induced diapause process reproduction in large bodied cladocerans (Santangelo et al., 2010; Slusarczyk, 2010; Slusarczyk et al., 2012). None of the sites studied in the Magallanes and Aysen region had zooplanktivorous fishes, and in these pools the main predator would have been the large-bodied copepod Parabroteas sarsi (De los Ríos-Escalante, 2010), an active zooplankton predator in Patagonian inland waters (Vega, 1996, 1997, 1998, 1999). However no studies have been carried out on chemical communication between predator and prey in Patagonian inland waters.

It is recorded in the literature that the diapause can be induced by climate changes that affect it at metapopulation and metacommunity levels (Alteratt \& Ebert, 2008; Altermatt et al., 2008). Drying periods directly affect diapause activity. The dormant eggs hatch during the flooding period (Alteratt \& Ebert, 2008; Altermatt et al., 2008), and the hatching process is enhanced by optimal temperature and photoperiod conditions (Vandekerkhove et al., 2005; Depuis \& Hann, 2009), resulting in a synchronized process in confined habitats (Nevalainen \& Sarmaja-Korjonen, 2008). Resting eggs can survive in sediments of ephemeral water bodies over many seasons, and when they hatch can give rise to individuals with different genetic characteristics from other individuals of the same species, which have hatched from more recent eggs. This would generate an effect of improvement in community robustness (Brendonck \& De Meester, 2003). On a population or species scale, the diapause is a rapid life strategy to obtain many resting eggs that can have marked genetic heterogeneity. When these eggs are spread to different environments, this could enhance the survival of optimal genes as a first step in a long term speciation process such as has successfully been recorded in the Daphnia genus (Coulborne et al., 1997; Taylor et al. 1998; Keerfoot \& Weider, 2004; Kerfoot et al. 2004). 


\section{BIOGEOGRAPHICAL IMPLICATIONS}

From a biogeographical view point, the diapause process can encourage dispersion, mainly by biological agents such as animals that transport dormant eggs. This scenario involves colonization at long distances to habitats with different environmental conditions (Jenkins \& Underwood, 1998; Suatoni et al., 2006), and would generate genetic isolation because only individuals with optimal genetic conformation would survive (Gajardo et al., 1995; Suatoni et al., 2006). In this scenario, genetic isolation would generate a long term speciation process with consequent reproductive isolation (De los Ríos \& Zúñiga, 2000; Gajardo et al., 2004; Suatoni et al., 2006). For this scenario to occur, any specific geographical zone would need to have the potential first ancestors, that would generate the respective spreading and colonization by resting eggs or other similar strategy (Suatoni et al., 2006). According to Menu-Marque et al., (2000), southern Patagonia is a dispersion zone from a common ancestor, which would explain the presence of both South American and Antarctic species together (Menu-Marque et al., 2000; Morrone, 2004; 2006). If we consider these records of the presence of an ancestor, and the dispersion of dormant eggs by biological agents such as migratory aquatic birds moving from south to north , this could explain the widespread distribution of Sub-Antarctic species in southern Patagonia.. On the other hand, the presence of southern South American species in Southern Patagonia, can be probably due to dormant eggs being carried north to south by migratory aquatic birds. This proposal would agree with center of origin idea, that indicates the presence of defined geographical zones that have the potential ancestors, where many varieties and greatest dominance of the taxon, can be found and the direction from the origin is indicated by the migration routes of birds (Crisci et al. 2003).

This could explain the presence of similar zooplankton communities structures in central and southern Patagonian plains between $46-53^{\circ} \mathrm{S}$ (De los Ríos-Escalante, 2010; 2012). A different situation would occur with another similar widespread species (B. gracilis) which is found in coastal and mountain ephemeral pools, in mountain zones in Patagonia and tropical South America (Menu-Marque et al., 2000). The marked differences between inland water fauna in Patagonia and the north of South America
(Menu-Marque et al., 2000; De los Ríos-Escalante et al., 2012) are due the absence of the physical barrier of the Andes mountains preventing species dispersion and the presence of migratory aquatic birds. This would explain the distribution patterns of branchiopods and copepods in the region(De los Ríos \& Zúñiga, 2000; Menu-Marque et al., 2000). This mechanism agrees with observations of Agius (2006), in a lake exposed to volcanic activity that had been recently colonized by Branchinecta gaini and Boeckella poppei. Nevertheless, there is still no evidence about diapause and dispersion process in Amphipods, to explain the geographical distribution of some widespread species such as $H$. chiloensis and $H$. patagonica.

\section{ACKNOWLEDGEMENTS}

The present study was financed by projects DID-UACH d2001-11, CONICYT-Chile (Doctoral Fellowship and Grant for support Doctoral Thesis), and the project MECESUP UCT 0804.

\section{LITEATURE CITED}

Adamowicz, S.J., T.R. Gregory, M.C. Marinone \& P.D.N. Hebert (2002). New insights into the distribution of polyploidy Daphnia: the Holoarctic revisited and Argentina explored. Molecular Ecology, 11: 1209-1217.

Agius, J.T. (2006). Tephra and ecological studies of limnopolar lake, Byers Peninsula, Livigston Island. PhD. Thesis, University of Tasmania, $151 \mathrm{p}$.

Alekseev V.R. (2007a). Diapause in crustaceans: peculiarities of induction. In: Alekseev. V.R. et al. (Eds). Diapause in Crustaceans. Springer. 29-63.

Alekseev V.R. (2007b). A brief perspective on molecular mechanisms of diapause in aquatic invertebrates. In: Alekseev. V.R. et al. (Eds). Diapause in Crustaceans. Springer. 115-118.

Alekseev V.R., O. Ravera \& B.T. De Stasio (2007). Introduction to diapause. In: Alekseev. V.R. et al. (Eds). Diapause in Crustaceans. Springer. 3-10.

Alekseev V.R. (2010). Physiological and molecular biological mechanisms underlying diapause in aquatic invertebrates. Russian Journal of 
Developmental Biology, 41: 61-70.

Altermatt, F. (2008). Ecological and evolutionary dynamics in Daphnia metapopulations. PhD Thesis Dissertation, University of Basel, Germany, 96 p.

Altermatt, F., I. Pajunen, D. Ebert (2008). Climate changes affects colonization dynamics in a metacommunity of three Daphnia species. Global Change Biology, 14: 1209-1220.

Altermat, F. \& D. Ebert (2008). The influence of pool volume and summer dissecation on the production of the resting and dispersal stage in a Daphnia metapopulation. Oecologia, 157: 441-452.

Banks, C.M. (2007). New Zealand Calanoid copepods invasions: has artificial lake construction facilitated invasions, and are our coastal waters uninvaded?. MSc Thesis, University of Waikato, New Zealand, 74 pp.

Bayley, S.A., K. Nandakumar, I.C. Duggan, C.D.A. van Overdijk, T.H. Johengen, D.F. Reid \& H.J. Maclsaac (2005). In situ hatching of invertebrate diapause eggs from ship's ballast sediments. Diversity and Distributions, 11: 453-460.

Brendonck, L. \& L. De Meester, (2003). Egg banks in freshwater zooplankton: evolutionary and ecological archives in the sediment. Hydrobiologia, 491: 65-84.

Campos, H., D. Soto, W. Steffen, O. Parra \& G. Agüero (1996). Limnological studies on Amarga lagoon, Chile: a saline lake in Patagonia, South America. International Journal of Salt Lake Research 4: 301-314.

Couch, K.M., M. Downes \& C.W. Burns, (2001). Morphological differences between subitaneous and diapause eggs of Boeckella triarticulata (Copepoda, Calanoida). Freshwater Biology, 46: 925-933.

Coulbourne, J.K. P.D.N. Hebert \& D. Taylor (1997). Evolutionary origins of phenotypic diversity in Daphnia. In: Molecular evolution and adaptive radiation. Givnish, T.J. \& K.J. Sytsna K.J. (Eds). Cambridge University Press, 163-168.

Crisci, J.V. L. Katinas \& P. Posadas (2003). Historical biogeography an introduction. Harvard University Press, U.S.A. 250 p.

De los Ríos-Escalante P. \& G. Gajardo (2010). Potential heterogeneity in crustacean zooplankton assemblages in southern Chilean saline lakes. Brazilian Journal of Biology, 70: 1031-1032. De los Ríos, P. \& O. Zúñiga (2000). Comparación biométrica del lóbulo frontal en poblaciones americanas de Artemia (Anostraca, Artemiidae). Revista Chilena de Historia Natural, 73: 31-38.

De los Ríos, P. \& G. Roa (2010). Species assemblages of zooplanktonic crustaceans in mountain shallow ponds of Chile (Parque Cañi). ZoologiaCuritiba, 27: 81-86.

De los Ríos-Escalante, P. (2010), Crustacean zooplankton communities in Chilean inland waters. Crustaceana Monographs 12: 1-109 p.

De los Ríos-Escalante, P. (2012). Crustacean zooplankton in Chilean ephemeral pools: an example for the study of metapopulations and metacommunities. Crustaceana 85:267-276.

De los Ríos-Escalante, P., J.J. Morrone \& R. Rivera (2012). Distributional patterns of South American species of Hyalella (Amphipoda: Hyalellidae). Gayana, 76: 153-161.

Depuis, A.P. \& B.J. Hann (2009). Climate change, diapause termination and zooplankton population dynamics: an experimental and modeling approach. Freshwater Biology, 54: 221-235.

Doobay, S. (2011). The utilization of the freshwater invertebrates Hyalella azteca and Daphnia magna for use in assessing potential endocrine disruption in aquatic systems. MSc Thesis, Ryerson University, Canada.

Dos Santos, A., Araujo, P. \& G. Bond-Buckup (2008). New species and new reports of Hyalella (Crustacea, Amphipoda, Dogielinotidae) from Argentina. Zootaxa, 1760: 24-36.

Ebert, D., C. Haag, M. Kirkpatrick, M. Riek, J.W. Hottinger \& V.I. Pajunen (2002). A selective advantage to inmigrant genes in a Daphnia metapopulation. Science, 18: 485-488.

Gajardo, G.M., M. Da Conceicao, L. Weber \& J.A. Beardmore (1995). Genetic variability and interpopulational differentiation of Artemia strains from South America. Hydrobiologia, 302: 21-29.

Gajardo, G.M., J. Crespo, A. Triantaphyllidis, A. Tzika, A.D. Baxenavis, I. Kappas \& T.J. Abatzopoulos (2004). Species identification of Chilean Artemia populations based on DNA RFLP analysis. Journal of Biogeography, 
31: 547-555.

Hall, C.J. \& C.W. Burns (2001). Hatching of Boeckella hamata (Copepoda: Calanoida) resting eggs from sediments of a tidally influenced lake. New Zealand Journal of Marine and Freshwater Research, 35: 235-238.

Jenkins, D.G. \& M.O. Underwood, (1998). Zooplankton may not disperse readily in wind, rain or waterfowl. Hydrobiologia, 387/388: 15-21.

Jiang, X., S. Zhao, Z. Xu, G. Wang, J. He \& M. Cai (2012). Abundance and age of viable eggs of the calanoid copepod Boeckella poppei Mrázek in sediments: evidence of egg banks in two Antarctic maritime lakes. Polar Biology, 35: 1525-1531.

Kerfoot, W.C. \& L.J. Weider (2004). Experimental paleoecology (resurrection ecology): chasing Van Valen's Red Queen hypothesis. Limnology \& Oceanography, 49: 1300-1316.

Kerfoot, W.C., X. Ma, C.S. Lorence \& L.J. Weider (2004). Toward resurrection ecology: Daphnia mendotae and D. retrocurva in the Coastal region of lake Superior, among the first successful outside invaders?. Journal of Great lakes Research, 30 (supplement, 1): 285-299.

Menu-Marque, S. J.J. Morrone \& C. Locasio de Mitrovich (2000). Distributional patterns of the South American species of Boeckella (Copepoda: Centropagidae): a track analysis. Journal of Crustacean Biology, 20: 262-272.

Morrone, J.J. (2004). Panbiogeografía, componentes bióticos y zonas de transición. Revista Brasileira de Entomologia, 48: 149-162.

Morrone, J.J. (2006). Biogeographic areas and transition zones of Latin America and the Caribbean island based on panbiogeographic analysis and cladistic analysis of the entomofauna. Annual Review of Entomology, 51: 467-494.

Muñoz, J. (2009). Implicaciones de la dispersion actual e histórica para la biología evolutiva y conservación de Artemia y otros invertebrados acuáticos con estado de diapausa. Tesis Doctoral, Universidad de Sevilla, España, 138 p.

Nevelainen, L. \& K. Sarmaja-Korjonen (2008). Timing of sexual reproduction in Chydorid cladocerans (Anomopoda, Chydoridae) from nine lakes in southern Finland. Estonian Journal of Ecology, 57: 21-36.
Pugh, P.J.A., H.J.G. Dartnall \& S.J. McInnes (2002). The non marine crustacea of Antarctica and the islands of the Southern Ocean: biodiversity and biogeography. Journal of Natural History, 36: 1047-1103.

Rogers, D.C., P. De los Ríos \& O. Zuniga, (2008). Fairy shrimp (Branchiopoda) of Chile. Journal of Crustacean Biology, 28: 543-550.

Santangelo, J.M., R.L. Bozelli, F. Esteves \& R. Tollrian (2010). Predation cues do not affect the induction and termination of diapause in small-bodies cladocerans. Freshwater Biology 55: 1577-1586.

Slusarczyk, M. (2009). Extended lifespan traded for diapause in Daphnia. Freshwater Biology, 54: 2252-2262.

Slusarczyk, M., A. Ochocka \& D. Cichocka (2012). The prevalence of diapause response to risk of size-defensive predation in small-and largebodied prey species. Aquatic Ecology, 46: 1-8.

Suatoni, E., S. Vicario, S. Rice, T. Snell \& A. Caccone (2006). An analysis of species boundaries and biogeographic patterns in a cryptic species complex: The rotifer Branchionus plicatilis. Molecular Phylogenetics and Evolution, 41: 86-88.

Taylor, A.M. (2010). Reducing establishment rates of non indigenous zooplankton in constructed waters. MSc Thesis, The University of Waikato, New Zealand, 94 p.

Taylor, D.J., T.L. Finston \& P.D.N. Hebert (1998). Biogeography of a widespread freshwater crustacean: pseudocongruence and cryptic endemism in the north American Daphnia laevis complex. Evolution, 52: 1648-1670.

Vandekerkhove, J., S. Declerck, L. Brendonck, J.M. Conde-Porcuna, E. Jeppensen \& L. De Meester (2005). Hatching of cladocerans resting eggs: temperature and photoperiod. Freshwater Biology, 50: 96-104.

Vega, M.P. (1996). Morphology and defensive structures in the predator-prey interaction: an experimental study of Parabroteas sarsi (Copepoda, Calanoida) with different cladoceran prey. Hydrobiologia, 299: 139-145.

Vega, M.P. (1997). The functional response of copepodid stages to adult of Parabroteas sarsi (Copepoda, Calanoida). International Review Gesamt Hydrobiologie, 154: 647-663. 
Vega, M.P. (1998). Impacts of Parabroteas sarsi (Copepoda, Calanoida) predation on planktonic cladocerans in a pond of the southern Andes. Journal of Freshwater Ecology, 13: 383-389.
Vega, M.P. (1999).Life-stage differences in the diet of Parabroteas sarsi (Daday) (Copepoda, Calanoida): a field study. Limnologica, 29: 186-190. 